\title{
FAKTOR RISIKO KEJADIAN KOMPLIKASI KARDIOVASKULER PADA PASIEN DIABETES MELITUS (DM) TIPE 2
}

\author{
Irfan*, Israfil \\ Dosen Jurusan Keperawatan Poltekkes Kemenkes Kupang, Nusa Tenggara Timur (NTT) \\ Jln. Piet. A. Tallo - Liliba Kupang, Kota Kupang, Provinsi NTT, 85111, Indonesia \\ E-mail: irfan1971kupang@gmail.com
}

\begin{abstract}
ABSTRAK
Tujuan penelitian: mengetahui faktor risiko: usia, jenis kelamin, tekanan darah, konsumsi obat, cek kesehatan, dan diet terhadap kejadian komplikasi kardiovaskuler pada pasien Diabetes Melitus Tipe 2 di Puskesmas Sikumana Kota Kupang. Metode: Desain penelitian yang digunakan adalah analitik non eksperimen dengan rancangan case control. Sampel penelitian sebanyak 74 orang pasien DM tipe 2 yang terbagi dalam 37 orang sampel kasus dan 37 orang sampel kontrol. Data hasil penelitian dianalisis dengan menggunakan uji statistik regresi logistik dengan nilai signifikan $\alpha<0,05$ dan $\mathrm{OR}>1$. Hasil: 51,4\% responden kelompok kasus mengalami komplikasi vaskuler ke otak (stroke non hemoragik/ $\mathrm{SNH}$ ), 37,8\% mengalami komplikasi vaskuler ke jantung (coronaria artery diseases/CAD), 8, 1\% responden kelompok kasus mengalami komplikasi SNH+coronary artery disease (CAD), dan 2,7\% mengalami Angina Pectoris. Faktor risiko komplikasi: usia $(\mathrm{p}=0,32, \mathrm{OR}=0,19)$, jenis kelamin $(\mathrm{p}=0,14, \mathrm{OR}=13,2)$, tekanan darah $(\mathrm{p}=0,034, \mathrm{OR}=0,02)$, konsumsi obat $(p=0,34, O R=43,9)$, kontrol kesehatan $(p=0,43, O R=0,53)$, diet $(p=0,009, O R=3,29)$. Kesimpulan: kejadian komplikasi kardio vaskuler pada pasien DM tipe 2 di Puskesmas Sikumana Kota Kupang dipengaruhi oleh tekanan darah yang tinggi dan diet yang kurang baik.
\end{abstract}

Kata Kunci: DM tipe 2, komplikasi kardiovaskuler, faktor risiko

\section{Risk Factor for the Occurrence of Cardiovascular Complications in Type 2 Diabetes Mellitus (DM) Patients}

\section{ABSTRACT}

Objective: the objective of the study is knowing risk factors: age, sex, blood pressure, drug consumption, health check, and diet for the occurrence of cardiovascular complications in Type 2 Diabetes Mellitus (DM) patients at Puskesmas Sikumana Kota Kupang. Methods: The research design used was non-experimental analytic with case control design. The study sample was 74 type 2 DM patients divided into 37 case samples and 37 control samples. Data were analyzed using logistic regression statistical tests with significant values $\alpha<0.05$ and OR>1. Results: The results showed $51.4 \%$ of case group respondents had vascular complications to the brain (non-haemorrhagic stroke/SNH), 37.8\% having vascular complications to the heart (coronary artery diseases/CAD), 8.1\% of case group respondents had $S N H+C A D$ complications, and 2.7\% had Angina Pectoris. Risk factors for complications; age ( $p=0.32, O R=0.19)$, sex $(p=0.14$, $O R=13.2)$, blood pressure $(p=0.034, O R=0.02)$, drug consumption $(p=0.34, O R=43.9)$, health control $(p=0.43$, $O R=0.53)$, diet $(p=0.009, O R=3.29)$. Conclusion: the incidence of cardio vascular complications in type 2 DM patients at the Sikumana Public Health Center in Kupang City was influenced by blood pressure and poor diet.

Keywords: DM type 2, cardiovascular complications, risk factors 


\section{LATAR BELAKANG}

Diabetes Melitus (DM) atau kencing manis merupakan salah satu penyakit kronis yang semakin serius mengancam kesehatan dan kehidupan manusia. DM tediri dari empat jenis yaitu DM tipe 1, DM tipe 2, DM yang berhubungan dengan keadaan atau sindrom lain, dan DM gestasional yang sering terjadi pada wanita hamil (McPhee \& Ganong, 2010). Kurang lebih 90-95\% penderita mengalami DM Tipe 2, yaitu diabetes yang tidak tergantung insulin. DM tipe 2 terjadi akibat penurunan sensitivitas insulin (resistensi insulin) akibat penurunan jumlah insulin. Faktor yang berhubungan dengan kejadian DM tipe 2 adalah usia, obesitas, riwayat keluarga, dan gaya hidup yang tidak sehat. DM tipe 2 umumnya dapat dicegah dengan perilaku hidup sehat seperti diet dan latihan fisik yang tepat (Smeltzer \& Bare, 2001).

Organisasi kesehatan dunia Wold Health Organisation (WHO) tahun 1998 dalam Departemen Kesehatan Republik Indonesia/ Depkes RI (2008) memprediksi kenaikan jumlah penyandang DM di Indonesia dari 8,4 juta pada tahun 2000 akan mencapai sekitar 21,3 juta pada tahun 2030. Badan Federasi Diabetes Internasional (International Diabetes Federation) pada tahun 2003 dalam Depkes RI (2008) memperkirakan jumlah penyandang DM dari 7,0 juta tahun 2009 akan naik menjadi 12,0 juta pada tahun 2030. Di Indonesia data Badan Pusat Statistik (BPS) juga menunjukkan bahwa jumlah penyandang diabetes pada tahun 2003 sebanyak 13,7 juta orang, berdasarkan pola pertambahan penduduk diperkirakan pada 2030 akan ada 20,1 juta penyandang diabetes dengan tingkat prevalensi 14,7 persen. Puskesmas Sikumana Kota Kupang juga menemukan terjadi peningkatan kasus DM Tipe 2 di wilayah kerja Puskesmas sejak tahun 2015.
Penyakit diabetes yang tidak ditangani dengan baik akan mengakibatkan hiperglikemia yang dari waktu ke waktu dapat mengakibatkan komplikasi berupa kerusakan berbagai sistem tubuh terutama sistem saraf dan pembuluh darah. Penyakit DM merupakan salah satu faktor risiko penting terjadinya penyakit jantung, stroke, neuropati, retinopati, dan gagal ginjal. Seorang penderita DM memiliki risiko kematian dua kali lebih cepat dibandingkan dengan bukan penderita DM (Kemenkes RI, 2014).

Penyebab komplikasi penyakit DM secara umum adalah hiperglikemia yang berkepanjangan yang disebabkan oleh berbagai faktor. Risiko komplikasi kardiovaskuler pada pasien DM tipe 2 akan mudah terjadi pada pasien yang memiliki kadar gula darah yang tinggi, tekanan darah yang tinggi, kolesterol darah yang tinggi, merokok, usia $>40$ tahun (Prediksi Risiko Komplikasi DM WHO dalam Kemenkes RI, 2104).

Pengendalian DM dilakukan dalam upaya pencegahan faktor risiko komplikasi DM Tipe 2 dengan langkah CERDIK dan PATUH. CERDIK artinya Cek kondisi kesehatan secara berkala, Enyahkan merokok, Rajin aktivitas fisik, Diet sehat dengan kalori seimbang, Istirahat yang cukup, dan Kendalikan stress. PATUH artinya Periksa kesehatan secara rutin dan ikuti anjuran dokter, Atasi penyakit dengan pengobatan yang tepat dan teratur, Upayakan beraktivitas fisik yang aman, Hindari rokok, alkohol dan zat karsinogenik lainnya. Penelitian ini penting dilakukan agar dapat mengidentifikasi secara dini berbagai faktor risiko komplikasi kardiovaskuler pada pasien DM Tipe 2 sehingga upaya pencegahan faktor risiko komplikasi dapat dilakukan secara dini dengan upaya yang tepat. 
Tujuan penelitian ini untuk mengetahui faktor risiko usia, jenis kelamin, tekanan darah, konsumsi obat, kontrol kesehatan dan diet terhadap kejadian komplikasi kardiovaskuler pada pasien DM Tipe 2 di Puskesmas Sikumana Kota Kupang.

\section{METODE}

Desain penelitian yang digunakan adalah analitik non eksperimen dengan rancangan case control untuk mengetahui faktor risiko kejadian komplikasi kardiovaskuler pada pasien DM tipe 2 di Puskesmas Sikumana Kota Kupang. Populasi adalah semua penderita DM Tipe 2 di wilayah kerja Puskesmas Sikumana Kota Kupang dengan jumlah 180 orang. Sampel terdiri dari dua kelompok sampel yaitu kasus 37 orang yang telah mengalami komplikasi kardio vaskuler sebagai kelompok kasus, dan sampel kontrol 37 orang lainya yang memenuhi kriteria inklusi sebagai kelompok kontrol.

Pengambilan sampel dilakukan untuk sampel kontrol dengan cara simple random sampling dimana setiap pasien diseleksi secara acak untuk mendapatkan sampel sesuai kriteria inklusi yaitu menderita DM Tipe 2, belum mengalami komplikasi, dapat membaca dan menulis, dan bersedia menjadi responden penelitian dengan menandatangani informed consent.

Variabel penelitian terdiri dari variabel independen yaitu faktor risiko komplikasi yaitu usia, jenis kelamin, tekanan darah tinggi, konsumsi obat, kontrol kesehatan dan diet. Variabel dependen yaitu komplikasi kardiovaskuler; stroke, CAD, retinopati, nefropati, dan gagal ginjal. Tekanan darah systole digunakan berdasarkan Perhimpunan Dokter Spesialis Kardiovaskular Indonesia (2015).

Instrumen yang digunakan dalam penelitian ini adalah kuesioner tentang faktor risiko komplikasi kardiovaskuler pada pasien DM tipe 2. Tekanan darah atau hipertensi ditetapkan berdasarkan diagnosis medis dokter. Diet pasien terdiri dari diet baik, cukup, kurang berdasarkan persentase jawaban responden pada kuesioner tentang diet yang dimodifikasi dari diet DM dari Depkes RI (2008). Konsumsi obat dikatakan patuh jika pasien mengkonsumsi obat sesuai resep dan anjuran dokter.

Data penelitian yang telah dikumpulkan dianalisis dengan menggunakan uji statistik regresi logistik dengan nilai signifikan $\alpha<0,05$ dan OR $>1$. Nama responden menggunakan inisial untuk menjaga kerahasiaan identitas responden. 
HASIL PENELITIAN

Tabel 1. Distribusi frekuensi karakteristik pasien DM Tipe 2 di Puskesmas Sikumana Kota Kupang Tahun 2018 ( $n=74)$.

\begin{tabular}{|c|c|c|c|c|c|c|}
\hline \multirow{3}{*}{ Karakteristik } & \multicolumn{4}{|c|}{ Responden } & \multirow{3}{*}{ Jumlah } & \multirow{3}{*}{ Persentase } \\
\hline & \multicolumn{2}{|c|}{ Kasus } & \multicolumn{2}{|c|}{ Kontrol } & & \\
\hline & $\mathrm{n}$ & $\%$ & $\mathrm{n}$ & $\%$ & & \\
\hline \multicolumn{7}{|l|}{ Usia } \\
\hline$<50$ Tahun & 0 & $0 \%$ & 4 & $10,80 \%$ & 4 & $5,40 \%$ \\
\hline 50-60 Tahun & 13 & $35,10 \%$ & 10 & $27,00 \%$ & 23 & $31,10 \%$ \\
\hline > 60 Tahun & 24 & $64,90 \%$ & 23 & $62,20 \%$ & 47 & $63,50 \%$ \\
\hline Jumlah & 37 & $100 \%$ & 37 & $100 \%$ & 74 & $100 \%$ \\
\hline \multicolumn{7}{|l|}{$\begin{array}{l}\text { Jenis } \\
\text { kelamin: }\end{array}$} \\
\hline Laki Laki & 18 & $48,60 \%$ & 14 & $37,80 \%$ & 32 & $43,20 \%$ \\
\hline Perempuan & 19 & $51,40 \%$ & 23 & $62,20 \%$ & 42 & $56,80 \%$ \\
\hline Jumlah & 37 & $100 \%$ & 37 & $100 \%$ & 74 & $100 \%$ \\
\hline \multicolumn{7}{|l|}{$\begin{array}{l}\text { Tingkat } \\
\text { pendidikan: }\end{array}$} \\
\hline SD & 8 & 21,6 & 6 & $16,20 \%$ & 14 & $18,90 \%$ \\
\hline SMP & 4 & $10,80 \%$ & 7 & $18,90 \%$ & 11 & $14,90 \%$ \\
\hline SMA & 15 & $40,50 \%$ & 18 & $48,60 \%$ & 33 & $44,60 \%$ \\
\hline Sarjana & 10 & $27,00 \%$ & 6 & $16,20 \%$ & 16 & $21,60 \%$ \\
\hline Jumlah & 37 & $100 \%$ & 37 & $100 \%$ & 74 & $100 \%$ \\
\hline
\end{tabular}




\begin{tabular}{|c|c|c|c|c|c|c|}
\hline \multirow{3}{*}{ Karakteristik } & \multicolumn{4}{|c|}{ Responden } & \multirow{3}{*}{ Jumlah } & \multirow{3}{*}{ Persentase } \\
\hline & \multicolumn{2}{|c|}{ Kasus } & \multicolumn{2}{|c|}{ Kontrol } & & \\
\hline & $\mathrm{n}$ & $\%$ & $\mathrm{n}$ & $\%$ & & \\
\hline \multicolumn{7}{|l|}{$\begin{array}{l}\text { Jenis } \\
\text { komplikasi: }\end{array}$} \\
\hline SNH & 19 & $51,40 \%$ & 0 & $0 \%$ & 19 & $51,40 \%$ \\
\hline CAD & 14 & $37,80 \%$ & 0 & $0 \%$ & 14 & $37,80 \%$ \\
\hline $\mathrm{SNH}+\mathrm{CAD}$ & 3 & $8,10 \%$ & 0 & $0 \%$ & 3 & $8,10 \%$ \\
\hline Anggina & 1 & $2,70 \%$ & 0 & $0 \%$ & 1 & $2,70 \%$ \\
\hline $\begin{array}{l}\text { Tidak } \\
\text { Komplikasi }\end{array}$ & 0 & $0 \%$ & 37 & $100 \%$ & 0 & $0 \%$ \\
\hline Jumlah & 37 & $100 \%$ & 37 & $100 \%$ & 37 & $100 \%$ \\
\hline
\end{tabular}

Tabel 2. Pengaruh usia pasien DM tipe 2 terhadap kejadian komplikasi kardiovaskuler di Puskesmas Sikumana Kota Kupang Tahun 2018 (n=74)

Kejadian Komplikasi

$95 \%$ C. I

$\begin{array}{llllll}\text { Usia Kasus } & \text { Kontrol Jmlah } & \% & \text { p } & \text { OR }\end{array}$

n $\quad \% \quad$ n $\quad \%$

Low Upp

\begin{tabular}{|c|c|c|c|c|c|c|c|c|c|}
\hline$<50$ & 0 & $0 \%$ & 4 & $10,8 \%$ & 4 & $\begin{array}{ll}5,4 \% & \\
0320\end{array}$ & 0,199 & 0,008 & 4,773 \\
\hline $50-60$ & 13 & $35,1 \%$ & 10 & $27,0 \%$ & 23 & $31,1 \%$ & & & \\
\hline$>60$ & 24 & $64,9 \%$ & 23 & $62,2 \%$ & 47 & $63,5 \%$ & & & \\
\hline Total & 37 & $100 \%$ & 37 & $100 \%$ & 74 & $100 \%$ & & & \\
\hline
\end{tabular}


Tabel 3. Pengaruh Jenis Kelamin Pasien DM tipe 2 dengan Kejadian Komplikasi Kardiovaskuler di Puskesmas Sikumana Kota Kupang tahun 2018 (n=74)

\begin{tabular}{|c|c|c|c|c|c|c|c|c|c|c|}
\hline \multirow{3}{*}{ Jenis Kelamin } & \multicolumn{4}{|c|}{ Kejadian Komplikasi } & \multirow{3}{*}{ Jmlah } & \multirow{3}{*}{$\%$} & \multirow{3}{*}{$\mathbf{p}$} & \multirow{3}{*}{ OR } & \multicolumn{2}{|c|}{$95 \%$ C. I } \\
\hline & \multicolumn{2}{|c|}{ Kasus } & \multicolumn{2}{|c|}{ Kontrol } & & & & & & \\
\hline & $\mathbf{n}$ & $\%$ & $\mathbf{n}$ & $\%$ & & & & & & \\
\hline Laki Laki & 18 & $48,6 \%$ & 14 & $37,8 \%$ & 32 & $43,2 \%$ & 0,14 & 13,2 & 0,42 & 413. \\
\hline Perempuan & 19 & $51,4 \%$ & 23 & $62,2 \%$ & 42 & $56,8 \%$ & & & & \\
\hline Total & 37 & $100 \%$ & 37 & $100 \%$ & 74 & $100 \%$ & & & & \\
\hline
\end{tabular}

Tabel 4. Pengaruh Tekanan Darah (systole) pasien DM tipe 2 dengan kejadian Komplikasi Kardiovaskuler di Puskesmas Sikumana Kota Kupang tahun $2018(n=74)$

Kejadian Komplikasi

$95 \%$ C.I

\begin{tabular}{|c|c|c|c|c|c|c|c|c|c|c|}
\hline \multirow{2}{*}{$\begin{array}{c}\text { Tekanan } \\
\text { Darah }\end{array}$} & \multicolumn{2}{|c|}{ Kasus } & \multicolumn{2}{|c|}{ Kontrol } & \multirow[t]{2}{*}{ Jmlah } & \multirow[t]{2}{*}{$\%$} & \multirow[t]{2}{*}{$p$} & \multirow[t]{2}{*}{ OR } & \multirow{2}{*}{ Low } & \multirow{2}{*}{ Upp } \\
\hline & $n$ & $\%$ & $n$ & $\%$ & & & & & & \\
\hline$>120-140$ & 5 & $13,5 \%$ & 21 & $56,8 \%$ & 26 & $35,1 \%$ & 0.034 & 0,020 & 0,00 & 0,74 \\
\hline$>140-160$ & 15 & $40,5 \%$ & 13 & $35,1 \%$ & 28 & $37,8 \%$ & & & & \\
\hline$>160-180$ & 12 & $32,4 \%$ & 3 & $8,1 \%$ & 15 & $20,3 \%$ & & & & \\
\hline$>180$ & 5 & $13,5 \%$ & 0 & $0 \%$ & 5 & $6,8 \%$ & & & & \\
\hline Total & 37 & $100 \%$ & 37 & $100 \%$ & 74 & $100 \%$ & & & & \\
\hline
\end{tabular}


Tabel 5. Pengaruh Kebiasaan konsumsi obat Pasien DM Tipe 2 terhadap kejadian komplikasi kardiovaskuler di Puskesmas Sikumana Kota Kupang Tahun 2018 (n=74)

\begin{tabular}{|c|c|c|c|c|c|c|c|c|c|c|}
\hline \multirow{3}{*}{ Konsumsi Obat } & \multicolumn{4}{|c|}{ Kejadian Komplikasi } & \multirow{3}{*}{ Jmlah } & \multirow{3}{*}{$\%$} & \multirow{3}{*}{$\mathbf{p}$} & \multirow{3}{*}{ OR } & \multicolumn{2}{|c|}{ 95\% C.I } \\
\hline & \multicolumn{2}{|c|}{ Kasus } & \multicolumn{2}{|c|}{ Kontrol } & & & & & & \\
\hline & $\mathrm{n}$ & $\%$ & $\mathrm{n}$ & $\%$ & & & & & & \\
\hline Patuh & 7 & $18,9 \%$ & 18 & $48,6 \%$ & 25 & $33,8 \%$ & & & & \\
\hline Tidak Patuh & 12 & $32,4 \%$ & 18 & $48,6 \%$ & 30 & $40,5 \%$ & 0,34 & 43,9 & 0,01 & 1,192 \\
\hline Tidak Konsumsi & 18 & $48,6 \%$ & 1 & $2,7 \%$ & 19 & $25,7 \%$ & & & & \\
\hline Total & 37 & $100 \%$ & 37 & $100 \%$ & 74 & $100 \%$ & & & & \\
\hline
\end{tabular}

Tabel 6. Pengaruh Kebiasaan Kontrol Kesehatan pada pasien DM tipe 2 terhadap kejadian komplikasi kardiovaskuler di Puskesmas Sikumana Kota Kupang tahun $2018(n=74)$

\begin{tabular}{|c|c|c|c|c|c|c|c|c|c|c|}
\hline \multirow{3}{*}{ Kontrol Kesehatan } & \multicolumn{4}{|c|}{ Kejadian Komplikasi } & \multirow{3}{*}{ Jmlah } & \multirow{3}{*}{$\%$} & \multirow{3}{*}{$p$} & \multirow{3}{*}{ OR } & \multicolumn{2}{|c|}{$95 \%$ C. I } \\
\hline & \multicolumn{2}{|c|}{ Kasus } & \multicolumn{2}{|c|}{ Kontrol } & & & & & & \\
\hline & $\mathrm{n}$ & $\%$ & $\mathrm{n}$ & $\%$ & & & & & & \\
\hline Rutin & 6 & $16,2 \%$ & 20 & $54,1 \%$ & 26 & $35,1 \%$ & & & & \\
\hline Kadang Kadang & 11 & $29,7 \%$ & 16 & $43,2 \%$ & 27 & $36,5 \%$ & & & & \\
\hline Tidak Pernah & 20 & $54,1 \%$ & 1 & $2,7 \%$ & 21 & $38,4 \%$ & 0,43 & 0,53 & 0,00 & 89,5 \\
\hline Total & 37 & $100 \%$ & 37 & $100 \%$ & 74 & $100 \%$ & & & & \\
\hline
\end{tabular}




\section{Tabel 7. Pengaruh Perilaku Diet pasien DM tipe 2 terhadap kejadian komplikasi kardiovaskuler di Puskesmas Sikumana Kota Kupang tahun 2018 (n=74)}

\begin{tabular}{|c|c|c|c|c|c|c|c|c|c|c|}
\hline \multirow{3}{*}{ Diet } & \multicolumn{4}{|c|}{ Kejadian Komplikasi } & \multirow{3}{*}{ Jmlah } & \multirow{3}{*}{$\%$} & \multirow{3}{*}{$p$} & \multirow{3}{*}{ OR } & \multicolumn{2}{|c|}{$95 \%$ C. I } \\
\hline & \multicolumn{2}{|c|}{ Kasus } & \multicolumn{2}{|c|}{ Kontrol } & & & & & & \\
\hline & $n$ & $\%$ & $n$ & $\%$ & & & & & & \\
\hline Baik & 0 & $0 \%$ & 20 & $54,1 \%$ & 20 & $27,0 \%$ & & & & \\
\hline Cukup & 7 & $18,9 \%$ & 16 & $43,2 \%$ & 23 & $31,1 \%$ & 0,009 & 3,29 & 7,75 & 1,40 \\
\hline Kurang & 30 & $81,1 \%$ & 1 & $2,7 \%$ & 31 & $41,9 \%$ & & & & \\
\hline Total & 37 & $100 \%$ & 37 & $100 \%$ & 74 & $100 \%$ & & & & \\
\hline
\end{tabular}

HASIL

Berdasarkan Tabel 1, diketahui bahwa sebagian besar responden $(63,5 \%)$ berusia $>60$ tahun, dan responden yang mengalami komplikasi sebagian besar berusia di atas $>60$ tahun $(64,9 \%)$. Sebagian besar responden $(56,8 \%)$ berjenis kelamin perempuan, dan responden yang mengalami komplikasi sebagian besar berjenis kelamin perempuan (51,4\%). Sebagian besar responden berpendidikan SMA (44,6\%), dan responden yang mengalami komplikasi sebagian besar berpendidikan SMA $(40,5 \%)$. Sebagian besar responden yang mengalami komplikasi adalah menderita stroke non haemoragic atau SNH $(51,4 \%)$, coronary artery diseases atau CAD $(37,8 \%)$, dan menderita SNH dan CAD sekaligus sebanyak $8,1 \%$.

Berdasarkan tabel 2, diketahui bahwa hasil analisis menggunakan uji statistik regresi logistik menunjukkan $p=0,320$. Hasil ini menunjukkan bahwa tidak ada hubungan yang signifikan antara usia pasien DM tipe 2 dengan kejadian komplikasi kardiovaskuler di Puskesmas Sikumana Kota Kupang.

Berdasarkan tabel 3, diketahui bahwa hasil analisis menggunakan uji statistik regresi logistik menunjukkan $p=0,141$. Hasil ini menunjukkan bahwa tidak ada hubungan yang signifikan antara jenis kelamin pasien DM tipe 2 dengan kejadian komplikasi kardiovaskuler di Puskesmas Sikumana Kota Kupang.

Berdasarkan tabel 4, diketahui bahwa bahwa sebagian besar responden pada kelompok kasus memiliki tekanan darah systole $>140 \mathrm{mmHg}(40,5 \%)$ dan $>160$ $\mathrm{mmHg}(32,4 \%)$, sedangkan responden pada kelompok kontrol sebagian besar memiliki tekanan darah systole $>120 \mathrm{mmHg}$ $(56,8 \%)$ dan $>140 \mathrm{mmHg}(35,1 \%)$. Hasil 
analisis menggunakan uji statistik regresi logistik menunjukkan $p=0,034$. Hasil ini menunjukkan bahwa ada hubungan yang signifikan antara tekanan darah pasien DM tipe 2 dengan kejadian komplikasi kardiovaskuler di Puskesmas Sikumana Kota.

Berdasarkan tabel 5, diketahui bahwa sebagian besar responden pada kelompok kasus tidak mengkonsumsi obat $(48,6 \%)$ dan tidak patuh dengan pengobatan $(32,4 \%)$, sedangkan responden pada kelompok kontrol sebagian besar responden patuh dengan pengobatan (48,6\%). Hasil analisis menggunakan uji statistik regresi logistik menunjukkan $p=0,34$. Hasil ini menunjukkan bahwa tidak ada hubungan yang signifikan antara kepatuhan minum obat pada pasien DM tipe 2 dengan kejadian kardiovaskuler di Puskesmas Sikumana Kota Kupang.

Berdasarkan tabel 6, diketahui bahwa sebagian besar responden pada kelompok kasus tidak pernah melakukan kontrol kesehatan $(54,1 \%)$ dan kadang-kadang $(29,7)$. Hasil analisis menggunakan uji statistik regresi logistik menunjukkan $p=0,43$. Hasil ini menunjukkan bahwa tidak ada hubungan yang signifikan antar kebiasaan kontrol kesehatan pada pasien DM tipe 2 dengan kejadian komplikasi kardiovaskuler di Puskesmas Sikumana Kota Kupang.

Berdasarkan tabel 7, diketahui bahwa sebagian besar responden pada kelompok kasus memiliki kebiasaan diet kurang baik $(81,1 \%)$, responden pada kelompok kontrol sebagian besar memiliki kebiasaan diet yang baik $(54,1 \%)$. Hasil analisis menggunakan uji statistik regresi logistik menunjukkan $p=0,009$. Hasil ini menunjukkan bahwa ada hubungan yang signifikan antara perilaku diet pasien DM tipe 2 dengan kejadian komplikasi kardiovaskuler di Puskesmas Sikumana Kota Kupang.

\section{DISKUSI}

Hasil penelitian ini menunjukkan bahwa sebagian besar penderita DM tipe 2 di Puskesmas Sikumana Kota Kupang telah mengalami berbagai jenis komplikasi kardiovaskuler. Komplikasi terbanyak adalah komplikasi vaskuler yaitu stroke non hemoragik/SNH $(51,4 \%)$, diikuti CAD $37,8 \%$, stroke non hemoragik + CAD 8,1\%, dan angina pectoris 2,7\%. Komplikasi DM dapat terjadi apabila faktor risiko DM yang dapat dimodifikasi tidak dapat dikendalikan atau diobati. Faktor risiko DM yang dapat dimodifikasi yaitu berat badan lebih, kurang aktivitas fisik, hipertensi, dyslipidemia, diet tidak seimbang, riwayat toleransi glukosa terganggu atau glukosa darah puasa terganggu, dan merokok (Kementerian Kesesehatan Republik Indonesia/Kemenkes RI, 2014).

Hasil penelitian ini menunjukkan tidak ada hubungan yang signifikan antara usia pasien DM tipe 2 dengan kejadian komplikasi kardiovaskuler di Puskesmas Sikumana Kota Kupang $(p=0,320)$. Hasil penelitian ini sesuai dengan hasil penelitian yang dilakukan Yuliani, Fadil, \& Iryani (2014) yang menunjukkan bahwa tidak ada hubungan yang bermakna atara usia dengan kejadian komplikasi PJK pada penderita DM tipe 2. Meskipun tidak memiliki hubungan yang signifikan, namun pada penelitian ini menunjukkan bahwa sebagian besar pasien DM tipe 2 yang mengalami komplikasi di Puskesmas Sikumana Kota Kupang berusia di atas 60 tahun $(64,9 \%)$.

Usia lebih dari 60 tahun merupakan usia lanjut dimana seseorang mengalami penurunan berbagai fungsi organ yang berpotensi munculnya berbagai penyakit degeneratif termasuk DM dan komplikasinya. Hal ini sesuai dengan yang dikemukaan Smeltzer \& Bare (2001) bahwa 
usia >60 tahun cenderung mengakibatkan peningkatan resistesni insulin. Peningkatan resistensi insulin yang tidak terkontrol pada pasien DM akan mengakibatkan hiperglikemia kronis yang berdampak pada kerusakan berbagai sistem organ yang disebut komplikasi DM.

Dari penelitian ini diketahui tidak ada hubungan yang signifikan antara jenis kelamin pasien DM tipe 2 dengan kejadian komplikasi kardiovaskuler di Puskesmas Sikumana kota Kupang $(p=0,14)$. Meskipun demikian, sebagian besar pasien DM tipe 2 yang mengalami komplikasi pada penelitian ini berjenis kelamin perempuan $(51,4 \%)$. Jenis kelamin perempuan merupakan jenis kelamin yang beresiko terkena DM dan bahaya komplikasinya.

Perempuan cenderung mengalami perubahan fungsi hormonal pada usia $>60$ tahun. Penurunan bebagai fungsi hormonal ini dapat berdampak pada perubahan fungsi hormon insulin yang bertanggung jawab atas kondisi DM (Smeltzer \& Bare, 2001). Penelitian Yuliani, Fadil, \& Iryani (2014) menunjukkan bahwa ada hubungan bermakna antara jenis kelamin dengan kejadian komplikasi PJK pada penderita DM tipe 2. Penelitian sebelumnya di Manado oleh William (2008) dalam Edwina, Manaf, \& Efrida (2015) menunjukkan bahwa DM tipe 2 lebih banyak terjadi pada perempuan daripada laki-laki.

Selanjutnya penelitian Fadhilah (2016) menunjukkan bahwa penyakit DM lebih banyak terjadi pada perempuan daripada laki laki. Kejadian komplikasi pada pasien DM yang lebih sering terjadi pada perempuan juga sesuai hasil penelitian Pratiwi (2010) dalam Lathifah (2017) yang menunjukkan bahwa perempuan yang menderita DM memiliki risiko lebih besar mengalami komplikasi kronis 1,253 kali lebih besar daripada laki-laki.
Hasil penelitian ini menunjukkan ada hubungan yang signifikan antar tekanan darah pasien DM tipe 2 dengan kejadian komplikasi kardiovaskuler di Puskesmas Sikumana Kota Kupang $(p=0,034)$. Sebagian besar responden pada kelompok kasus memiliki tekanan darah yang tinggi (systole) yaitu $>140 \mathrm{mmHg}$ sebanyak 40,5\%, >160 $\mathrm{mmHg} 32,4 \%$ dan terdapat $13,5 \%$ yang memiliki tekanan darah yang sangat tinggi yaitu $>180 \mathrm{mmHg}$.

Tekanan darah tinggi merupakan faktor risiko yang berpengaruh terhadap kejadian komplikasi kardiovaskuler pada pasien DM tipe 2. DM tipe 2 atau diabetes melitus merupakan suatu kondisi dimana terjadinya hiperglikemia atau peningkatan kadar glukosa dalam darah. Hiperglikemia yang tidak terkontrol akan mengakibatkan viskositas darah pasien meningkat pada setiap aliran darahnya. Peningkatkan viskositas darah pada DM tipe 2 akan mengakibatkan peningkatan beban jantung untuk memompa darah ke seluruh tubuh. Peningkatan tekanan darah yang yang berlangusung kronis pada penderita DM mengakibatkan penurunan perfusi oksigen pada berbagai jaringan dan organ tubuh. Penurunan perfusi jaringan ini diperburuk dengan kondisi hiperglikemia yang akhirnya terjadi hipoksia jaringan. Hipoksia pada jaringan otak akan mengakibatkan komplikasi stroke non hemoragik, dan hipoksia pada jaringan jantung mengakibatkan komplikasi penyakit jantung koroner atau CAD (McPhee \& Ganong, 2010).

Hasil penelitian ini sesuai dengan informasi dari Kementerian Kesehatan Republik Indonesia/Kemenkes RI (2014) bahwa risiko komplikasi akan sangat tinggi terjadi pada penderita DM yang disertai dengan tekanan darah yang tinggi. Hasil penelitian ini juga sesuai dengan penelitian Yuliani, Fadil, \& Iryani (2014) yang menunjukkan ada hubungan yang bermakna antar 
hipertensi dengan kejadian komplikasi PJK pada penderita DM tipe 2 .

Hasil penelitian ini menunjukkan tidak ada hubungan yang signifikan antara pengobatan dengan kejadian komplikasi kardiovaskuler pada pasien DM tipe 2 di Puskesmas Sikumana Kota Kupang $(p=0,34)$. Meskipun pengobatan tidak memiliki pengaruh yang signifikan dengan kejadian komplikasi kardiovaskuler, dari penelitian ini diketahui bahwa sebagian besar pasien DM tipe 2 yang mengalami komplikasi tidak mengkonsumsi obat $(48,6 \%)$ dan sebagian besar lainnya tidak patuh dengan pengobatan $(32,4 \%)$. Distribusi kepatuhan konsumsi obat pasien DM tipe 2 pada kelompok kasus penelitian ini sesuai dengan pernyataan Kemenkes RI (2014) bahwa pencegahan komplikasi dan perpanjangan usia penderita DM dapat dilakukan dengan terapi pengobatan yang rutin. Jika pasien tidak patuh dalam pengobatan yang ditetapkan, maka risiko komplikasi akan mudah terjadi akibat hiperglikemia kronis yang tidak dikendalikan.

Hasil penelitian ini menunjukkan tidak ada hubungan yang signifikan antara kebiasaan kontrol kesehatan dengan kejadian komplikasi kardiovaskuler pada pasien DM tipe 2 di Puskesmas Sikumana Kota Kupang $(p=0,43)$. Meskipun tidak memiliki pengaruh yang signifikan tehadap kejadian komplikasi kardiovaskuler, diketahui bahwa sebagian besar penderita DM tipe 2 yang telah mengalami komplikasi memiliki riwayat tidak pernah melakukan kontol atau cek kesehatan secara berkala $(54,1 \%)$, dan sebagian besar lainnya $29,7 \%$ tidak rutin dalam melakukan pemeriksaan atau cek kesehatan. Distribusi ini sesuai dengan pernyataan Kemenkes RI (2015) bahwa pencegahan dan penanggulangan penyakit kronis termasuk DM dapat dilakukan dengan cara CERDIK dan PATUH yang di dalamnya berisi cek dan periksa kesehatan secara berkala dan ikuti anjuran dokter.

Pemeriksaan kesehatan secara rutin sangat penting dilakukan bagi penderita DM tipe 2. Pemeriksaan secara berkala akan mengetahui status kesehatan dan memantau keberhasilan setiap terapi pengobatan yang telah diperoleh. Penemuan secara dini kondisi kesehatan dan keberhasilan pengobatan DM tipe 2 dapat membantu pasien dan petugas kesehatan untuk memberikan penanganan lebih intensif dalam pencegahan komplikasi kardiovaskuler penyakit DM tipe 2. Pemerintah telah menetapkan CERDIK dan PATUH dalam upaya penanganan dan pencegahan komplikasi berbagai penyakit kronis termasuk DM. C pada kata Cerdik berarti cek kesehatan secara berkala, dan $P$ pada kata Patuh adalah periksa kesehatan secara berkala dan ikuti anjuran dokter.

Hasil penelitian ini menunjukkan ada hubungan yang signifikan antara diet pasien DM tipe 2 dengan kejadian komplikasi kardiovaskuler di Puskesmas Sikumana Kota Kupang $(p=0,00)$. Pada penelitian ini, sebagian besar penderita DM yang telah mengalami komplikasi kardiovaskuler memiliki riwayat diet yang kurang baik $(81,1 \%)$. Penelitian ini sesuai dengan hasil penelitian yang dilakukan Putro \& Suprihatin (2012) yang menunjukkan bahwa ada hubungan yang signifikan antar diet tepat jumlah dengan kadar normal gula darah puasa $(p=0,000)$ yang merupakan indikator besar kecilnya risiko komplikasi pada penderita DM.

Diet yang kurang baik dapat mengakibatkan hiperglikemia yang tak terkontrol. Hiperglikemia tak terkontrol yang berlangsung secara kronis dapat mengakibatkan kerusakan berbagai organ tubuh. Penyumbatan pembuluh darah akibat tingginya viskositas darah karena hiperglikemia akan mudah terjadi 
yang berdampak pada cepatnya pasien mengalami komplikasi. Pencegahan hiperglikemia ini dapat dilakukan dengan diet yang tepat. Hal ini telah ditetapkan oleh Kemenkes RI (2014) bahwa upaya penanggulangan dan pencegahan komplikasi DM dapat dilakukan dengan diet dan atur pola makan yang tepat.

\section{SIMPULAN}

Pasien DM tipe 2 di Puskesmas Sikumana Kota Kupang mengalami komplikasi jenis $\mathrm{SNH}$, coronary artery diseases (CAD), angina pectoris, dan gabungan stroke non haemoragik + coronaria artery diseases (SNH+CAD). Kejadian komplikasi kardiovaskuler pada pasien DM tipe 2 di Puskesmas Sikumana Kota Kupang dipengaruhi oleh tekanan darah yang tinggi dan diet DM yang kurang baik. Pasien DM tipe 2 yang memiliki tekanan darah yang tinggi memiliki risiko komplikasi kardiovaskuler 0,02 kali lipat, sedangkan pasien yang tidak mematuhi diet DM dengan baik memiliki risiko komplikasi kardiovaskuler 3,29 kali lipat dibandingkan dengan pasien yang mematuhi diet DM dengan baik.

\section{DAFTAR PUSTAKA}

Edwina, D. A, Manaf, A., Efrida. (2015). Pola Komplikasi Kronis Penderita DM tipe 2 Rwat Inap di Bagian Penyakit dalam RS. Dr. M. Djamil Padang Januari 2011-2012. Jurnal Kesehatan Andalas, 4(1): 102-106.

Fadhilah, M. (2016). Gambaran Tingkat Risiko dan Faktor Faktor yang Berhubungan dengan Risiko DM tipe 2 di Buaran, Serpong. Jurnal Kedokteran Yarsi, 24(3): 186-202.
Kemenkes RI. (2014). Infodatin Waspada Diabetes Melitus. Jakarta: Pusat Data dan Informasi Kementerian Kesehatan RI.

Lathifah, N. L. (2017). Hubungan Durasi Penyakit dan kadar Gula Darah dengan Keluhan Subjektif Penderita Diabetes Melitus. Jurnal Berkala Epidemiologi, 5(2): 231-239.

McPhee, J. S. \& Ganong, F.W. (2010). Pathophysiology of Disease: An Introduction to Clinical Medicine. (Alih bahasa: Brahm U Pendit). Jakarta: Penerbit Buku Kedokteran EGC.

Perhimpunan Dokter Spesialis Kardiovaskular Indonesia. (2015). Pedoman Tatalaksana Hipertensi pada Penyakit Kardiovaskular. Jakarta: Perhimpunan Dokter Spesialis Kardiovaskular Indonesia.

Putro, P. J. S. \& Suprihatin. (2012). Pola Diit Tepat Jumlah, Jadwal, dan Jenis Terhadap Kadar Gula Darah Pasien diabetes mellitus Tipe 2. Jurnal Stikes, 5(1): 71-81.

Smeltzer, S.C. \& Bare, B. G. (2001). Brunner and Suddarth's textbook of medical surgical nursing. (Alih bahasa: Agung Waluyo, Yasmin Asih, Juli, Kuncara, I Made Kariasa). Jakarta: Penerbit Buku Kedokteran EGC. (Buku asli diterbitkan 1996).

Yuliani F., Fadil, F. \& Iryani, D. (2014). Hubungan Berbagai Faktor Risiko Terhadap Penyakit Jantung Koroner pada Penderita DM Tipe 2. Jurnal Kesehatan Anadalas: 3(1): 37-40. 